\title{
The Technique of Scarless Latissimus Dorsi in Immediate Breast Reconstruction
}

\author{
Cătălin Stîngu* \\ Ponderas Academic Hospital, Life Memorial Hospital, Bucharest, Romania
} Cătălin Stîngu, MD

Ponderas Academic Hospital Life Memorial Hospital, Bucharest Romania

E-mail: stingcat@gmail.com
*Corresponding author:

\section{Rezumat}

Tehnica de recoltare a lamboului muscular latissimus dorsi în reconstucția mamară imediată

Fondul problemei: În reconstrucția mamară cu implant plasat parțial submuscular (pectoral mare, serratus) problema acoperirii şi definirii polului inferior al sânului reconstruit a constituit o preocupare importantă de-a lungul anilor. Numeroase tehnici au fost introduse, şi studiate intensiv, printre care utilizarea substituenților sintetici sau biologici. Aceste tehnici au fost desemnate pentru a obține un rezultat estetic bun, pentru a oferi un suport mecanic puternic pentru implant şi pentru a oferi o flexibilitate în adaptarea volumului inițial al unui expander tisular la învelişul cutanat restant după mastectomie. Există situații clinice în care lambourile de mastectomie pot avea probleme de viabilitate vasculară, putând genera necroze parțiale în cursul evoluției postoperatorii. Acest fenomen este greu de predictat şi poate duce la complicații majore - expunerea implantului, extruzia acestuia precum şi expunerea şi infecția substituenților sintetici sau biologici, evenimente care pot genera eşecul procesului reconstructiv. Metodă: Tehnica de recoltare a lamboului muscular latissimus dorsi folosind incizia pentru mastectomie (recoltare minim invazivă) a fost folosită la pacientele eligibile pentru mastectomie cu prezervarea întregului înveliş cutanat al sânului cu sau fără păstrarea complexului areolo-mamelonar. Tehnica reconstructivă s-a bazat pe principiul plasării implantului în buzunar sub-pectoral şi sub serratus anterior iar polul inferior al implantului a fost acoperit cu lambou muscular latissimus dorsi recoltat prin incizia pentru mastectomie. Principalele etape ale intervenției chirurgicale sunt descrise în articol.

Rezultate: Principalele obiective ale acestui tip de reconstrucție 
mamara sunt stabilitatea şi definirea corecta a polului inferior al sânului. Interfața tisulară între implant şi tegument este reprezentată de țesutul muscular care previne expunerea şi extruzia implantului mamar. În cazul apariției unor zone necrotice ale lambourilor de mastectomie, vindecarea secundară este regula. Această tehnică diminuează în mod categoric morbiditatea intervenției prin evitarea riscurilor asociate cu schimbarea poziției pacientului în decubit lateral în timpul intervenției, rezultat estetic superior datorită eliminării inciziilor suplimentare din regiunea spatelui pentru abordul lamboului.

Concluził: Tehnica minim invazivă de prelevare a lamboului muscular latissimus dorsi pentru reconstrucția mamară cu implant plasat submuscular reprezintă o opțiune valoroasă şi o alternativă viabilă pentru utilizarea substituenților sintetici şi biologici.

Cuvinte cheie: mastectomie, lambou muscular latissimus dorsi, reconstrucția mamară

\begin{abstract}
Background: In dealing with the inferior pole coverage of an implant or a tissue expander in the partial submuscular technique, various surgical strategies have been introduced over the years. Among them, ADM and synthetic meshes were intensively studied and performed in order to obtain a good aesthetic result with satisfactory lower pole contouring, create a strong support of the implant and offer flexibility in adapting the volume of a tissue expander to the remaining mastectomy flaps $(1,2)$. However, the viability of the skin from the mastectomy flaps is not always optimal. Vascular impairment and subsequent necrosis can occur at various extent in the mastectomy flaps (3). The necrosis of the mastectomy flaps is unpredictable and sometimes occurs with no obvious cause (4). Implant exposure and extrusion, $\mathrm{ADM}$ or mesh exposure are serious complications which can lead to the reconstructive failure.

Methods: The scarless latissimus dorsi flap technique was introduced and observed in patients eligible for skin sparing and nipple sparing mastectomy with implant-based submuscular breast reconstruction. The keypoints of the surgical steps are described.

Results: The main priorities of the outcome of the reconstructive process were stability and good definition of the lower pole of the reconstructed breast. The good vascularized underlying muscular tissue totally covering the implant increases chances in avoiding exposure or extrusion of the implant. In the advent of partial mastectomy flap necrosis, the healing by secondary intention provided good and stable results. Also, this technique decreases the morbidity and risks related with the change of the patient position during the procedure, improves the aesthetic results, by avoiding additional incisions for harvesting the flap.

Conclusions: The scarless latissimus dorsi flap in implant based breast reconstruction is a valuable option for stable results and viable alternative to the use of ADM.
\end{abstract}

Key words: mastectomy, scarless latissimus dorsi flap, breast reconstruction

\section{Introduction}

In order to limit the above complications, a good option is represented by total muscular coverage of the implant or the tissue expander. In this way, the necrosis of the vascular impaired mastectomy flap would expose the muscular tissue instead of the device used for breast reconstruction, ADM included. Thus, this exposure can be easily treated conservatively or with minimal secondary surgery revision, decreasing the chances of loosing the implant.

For the lower pole of the new breast, the most accessible and reliable is the latissimus dorsi flap which can be harvested as a muscle 
flap by incisions oriented among the relaxing skin lines in the back or along the bra projection portion (5) (Fig. 1). A valid criticism of the latissimus dorsi flap harvest is the need for an additional incision and scar in the donor area.

This is not the case for biological or synthetic meshes. However, a refinement in the harvest of the latissimus dorsi muscular flap was introduced by the work of Elliot and Lee $(4,6)$. The authors advocated the dissection of the flap through the incision for the mastectomy - periareolar, periareloar with lateral extension or lateral with or without axillar prolongation.

The Australian team further improved the technique by not changing the patient position during surgery into the lateral decubitus, thus shortening the operative time (4). The consistent work of the above mentioned authors offered a good and reliable method of providing well vascularized tissue in completing the breast reconstruction with implants and tissue expanders. They reported good aesthetic results, stable implant and expander coverage, limited complications compared to those associated with ADM and synthetic meshes (seroma, infections and implant exposure avoided).

This paper presents the introduction and description of this technique in our practice.

\section{Material and Methods}

Since 2019 we have introduced this technique in patients eligible for skin sparing or nipple sparing mastectomy with immediate implant based breast reconstruction. We had so far 18 patients from which 6 of them had double breast reconstruction by this technique.

\section{Surgical Technique}

Since, the surgery is accurately described in the original papers by Franklin Elliot and Mark Lee, we would like only to ascertain some key points of the surgical steps.

1. The patient positioned in the dorsal decubitus with additional support and slight elevation of the trunk by means of

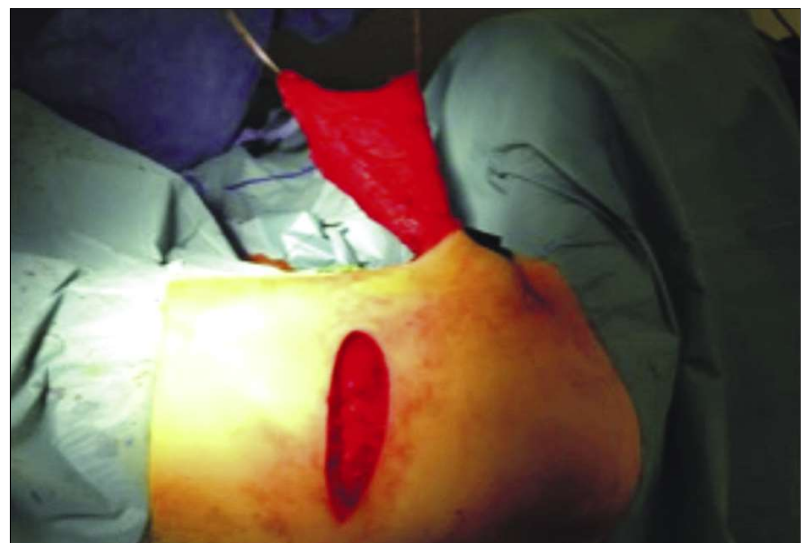

Figure 1. Latissimus dorsi muscular flap harvested by an incision projected on the bra line

padding in the shoulder and lumbar areas (Fig. 2). No need for changing position into the lateral decubitus during surgery. Preoperative markings are the infra-mammary fold, lateral breast line, which in many cases has to be repaired after completion of the reconstruction.

2. Along with usual breast surgical instruments, a light retractor and a bipolar vessel sealing system are mandatory.

3 . By means of retraction of the mastectomy incision the anterior margin of the latissimus dorsi and the key landmark, the inferior scapula fat pad, are identified. This is the point of posterior muscle division.

4. Dissection is continued alternatively subcutaneous and beneath the muscle to

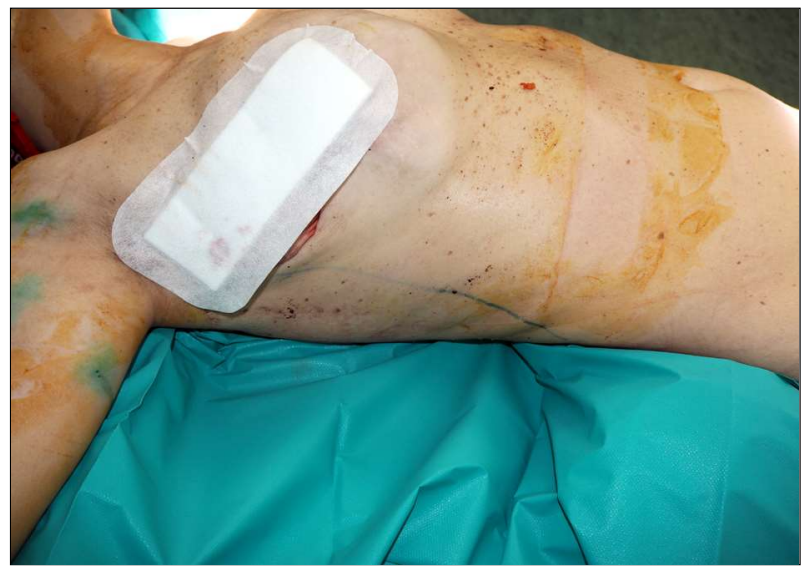

Figure 2. Padding under the arm with the patient slightly elevated from the operating table surface 
the lumbar area. Consistent amounts of muscular tissue can be harvested. The dissection towards the posteromedial is easier in the ventral part, thus providing additional amount of tissue. The caudal and medial portion of the muscle is divided by means of a bipolar sealing system. Dissection progresses cranially to the serratus branch of the thoracodorsal pedicle which can be divided or leaved in place according to the need of arch of rotation. The muscle is separated from the teres major and the thoracodorsal pedicle is identified and protected. The thoracodorsal pedicle is dissected and isolated (Fig. 3). With the pedicle on constant vision the fibrous part of the latissimus dorsi tendon is divided and detached, gaining additional coverage potential (Fig. A).

5. The fully islanded flap is transposed towards the anterior midline (Fig. 5) and sutured to the medial and inferomedial portions of the breast, to the pectoralis major and to the inframammary fold, providing total muscular implant coverage (Figs. 6, 7). Suturing is made in our practice after implant placement in the subpectoral pocket. Even if it seems tedious, by suturing the muscle with the implant in place, the suture tension can be adequately controlled in order to avoid marginal necrosis of the flap by excessive stretching.

6. It is reasonable to limit this technique at thin patients and with implants not exceeding $350 \mathrm{cc}$ in volume. However, with good exposure provided by generous mastectomy incision and effective retraction, long and large amounts of muscular flap can be harvested. Implants up to 500 cc with high profile can be totally covered in these cases.

\section{Results}

At this early stage, the outcomes are very promising (Figs. 8, 9, 10,11). The surgical technique provides in all cases stable coverage,

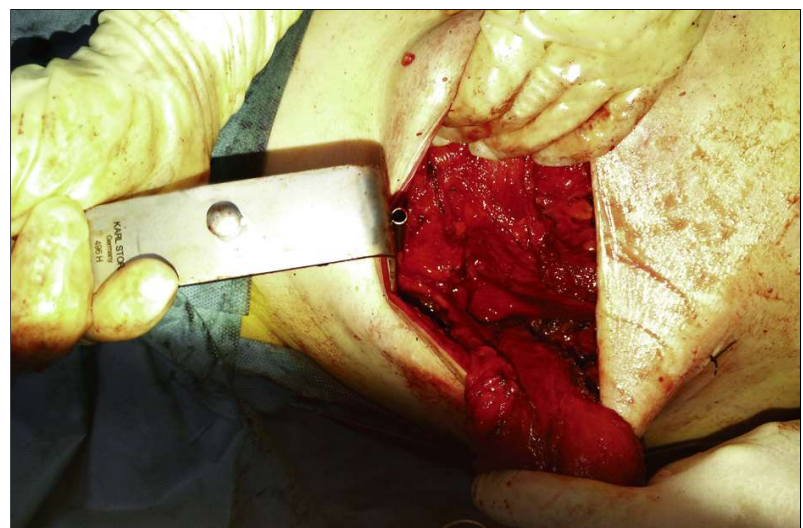

Figure 3. Thoracodorsal pedicle fully dissected

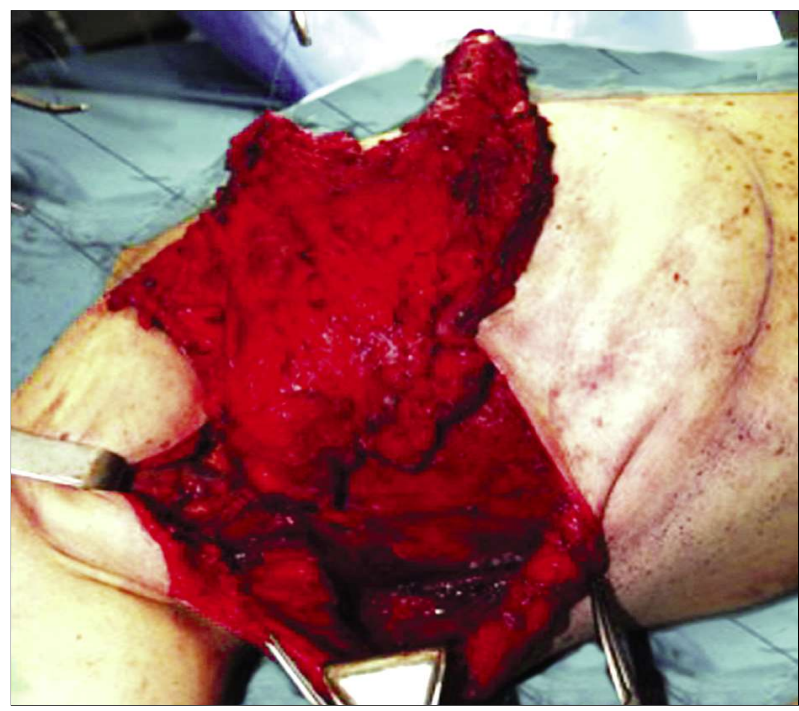

Figure 4. Tendon totally transected to gain full arch of rotation

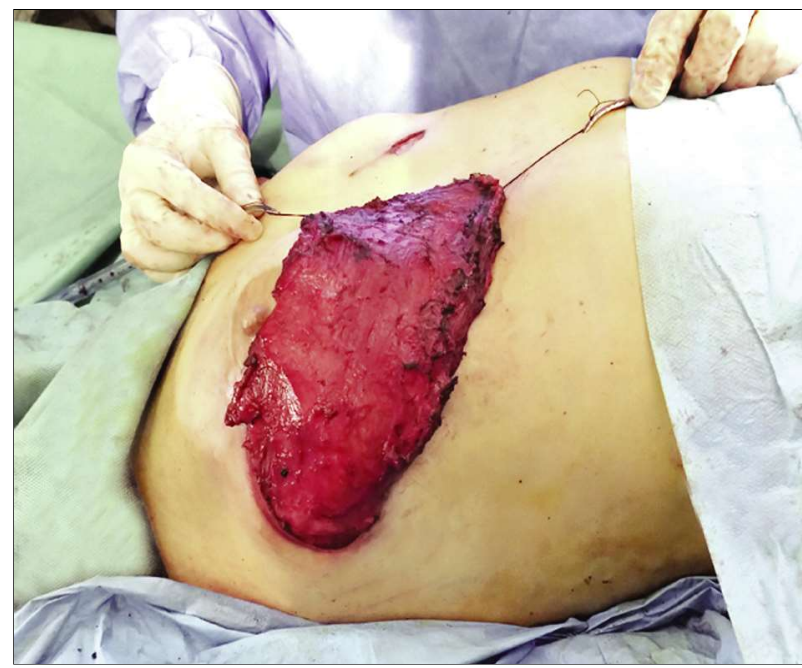

Figure 5. The flap transposed to the midline with the implant in place 


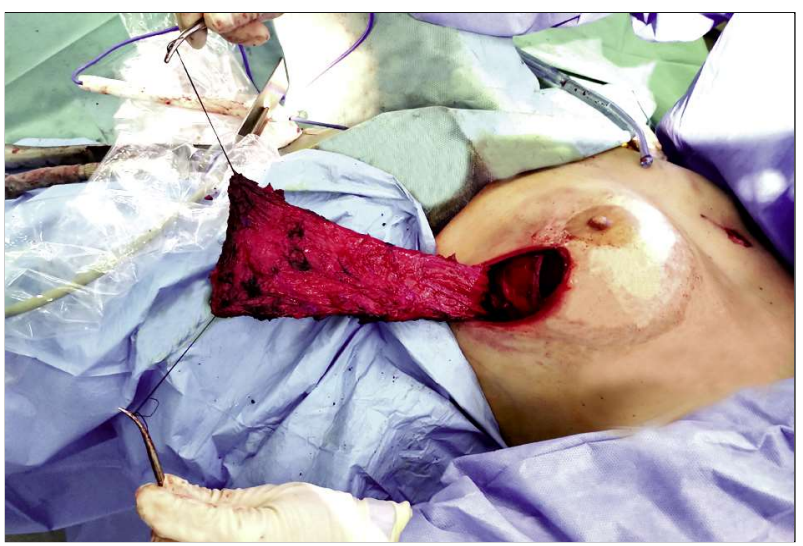

Figure 6. Tension free closure of the flaps

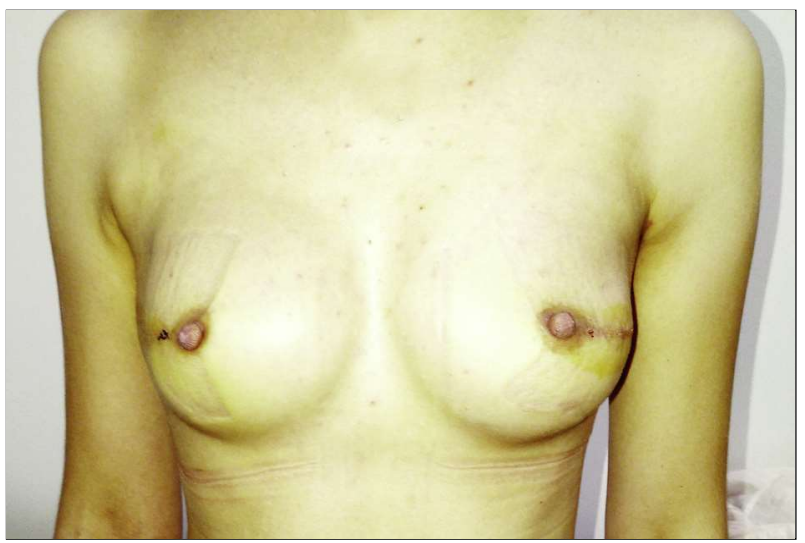

Figure 8. Early results with stable reconstruction

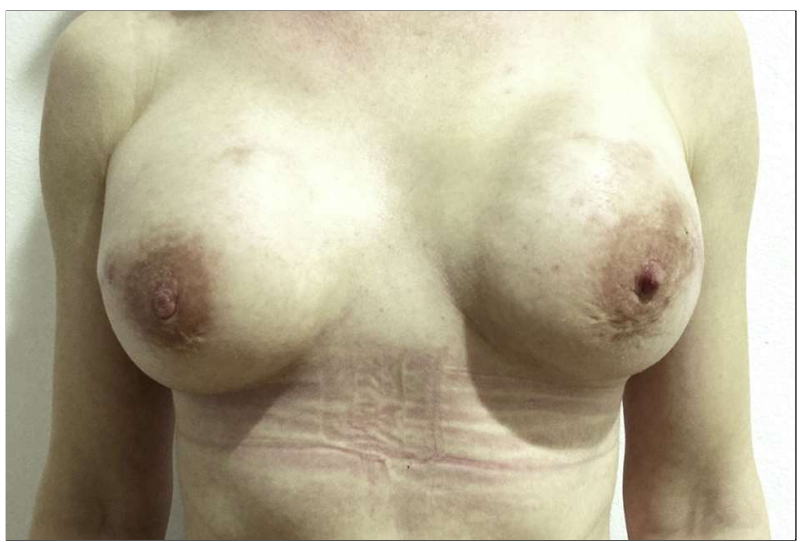

Figure 10. Early results with stable reconstruction

good definition of the lower pole with no implant exposure or loss. In two cases minimal partial necrosis of the mastectomy flaps were noted with healing by secondary intention and acceptable scarring. In one case

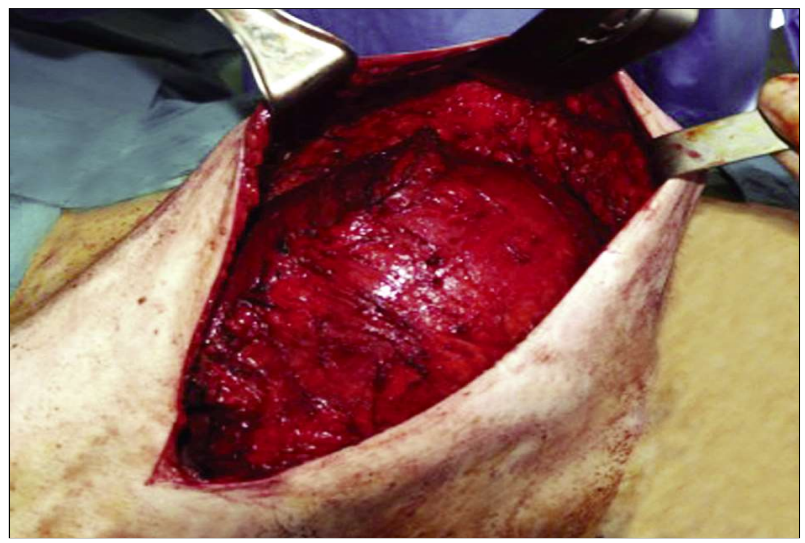

Figure 7. Total muscular coverage of the implant

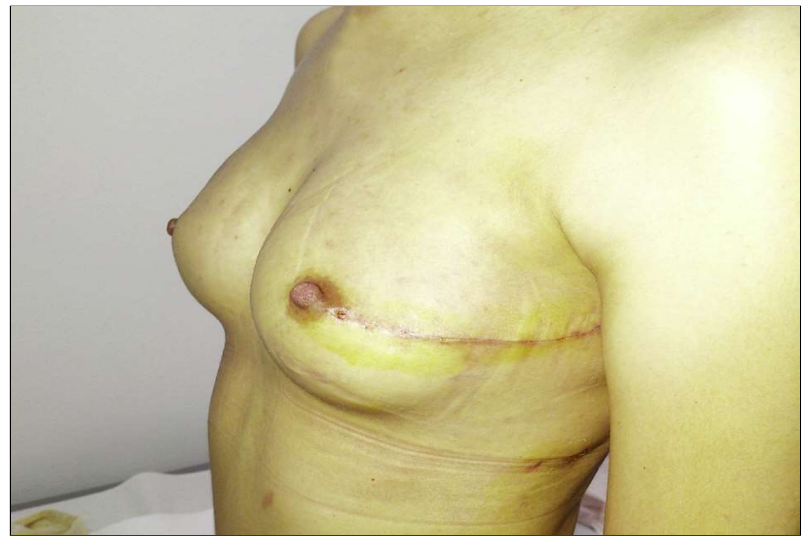

Figure 9. Early results with stable reconstruction

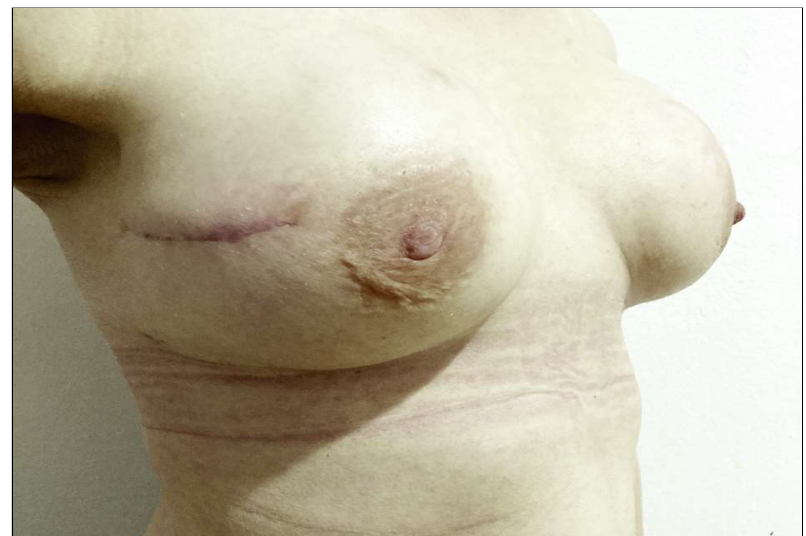

Figure 11. Early results with stable reconstruction

after NAC necrosis, late nipple reconstruction and areola tattooing were performed. In one case early marginal necrosis of the latissimus dorsi was noticed due to drainage change in color and inflammatory skin reaction in the 
inferomedial part of the breast. Emergency surgery was performed with debridement, repeated cleansing with antibiotic solution, implant replacement with total muscular coverage. The postoperative result provided stable reconstruction with no further complications.

\section{Discussions}

Implant-based breast reconstruction (IBBR) is the most commonly used technique and offers a safe, simple approach to reconstructive surgery $(7,8)$. In the context of the total or partial subpectoral- serratus anterior implant placement, the lower pole of the breast can be inadequately contoured. The total pectoralserratus placement can be often tight and prone to implant malposition and capsular contracture. The partial subpectoral placement leaves the inferior part of the implant underneath the skin and subcutaneous tissue which is a concern for further rippling and capsular contracture (9).

The advent of ADM (acellular dermal matrix) provided a lot of advantages - welldefining breast lower pole, stabilizing the pocket inferiorly and laterally, preventing the capsular contracture in many cases and minimizing operative time $(10,11)$.

However, the literature data suggest on long-term surveys increased rates of seroma and infection in the use of ADM in implantbased breast reconstruction $(12,13,14)$.

The main problem in the implant based breast reconstruction is the implant exposure or extrusion, capsular contracture or implant malposition due to overlying skin necrosis. In order to prevent that, reconstructive surgeons need a vascularized tissue to cover the implant in its entirety. The latissimus dorsi flap is in most cases the first option for this reconstructive purpose $(15,16)$.

But in most cases, the flap harvest needed an additional incision on the patient back according to reconstructive needs. The scarless technique provides adequate amount of tissue, with no additional scars, minimal

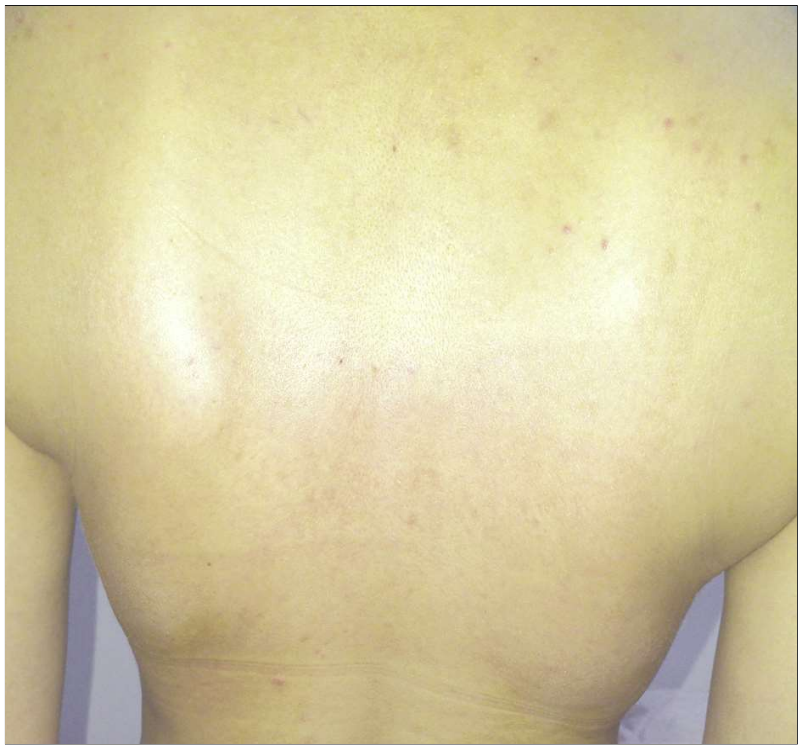

Figure 12. No additional scars and minimal deformity in the donor area

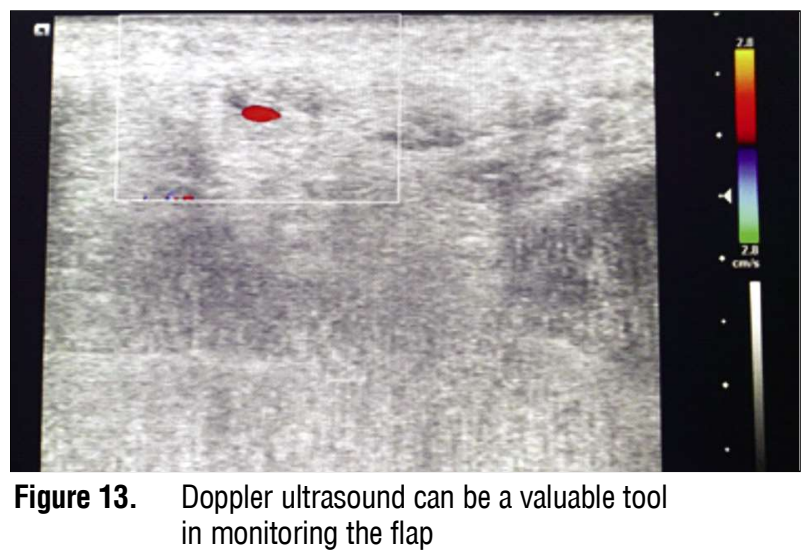

donor site deformity (Fig. 12) and no changing in the position of the patient during surgery, thus minimizing operative time and risks related. The aesthetic results can be comparable with the other methods of contouring the lower pole and the risk of device exposure and reconstructive failure is dramatically decreased. Even if monitoring a buried flap can be difficult, the Doppler ultrasonography can evaluate the vascular status of the flap and also the presence of hematomas or seromas (Fig. 13).

Even no technique is ideal in breast reconstruction, the scarless latissimus dorsi flap fulfills the reconstructive surgery goals of the 
breast - minimizing scars, shortening the operative time and decreasing the hospital stay.

\section{Conclusions}

This technique of scarless latissimus dorsi flap is a good option in the armamentarium of the breast reconstructive surgeon. It reduces the risk of implant exposure in the case of the skin necrosis in the mastectomy flap. It uses standard breast instruments, requires no special training, is able to be used also in association with tissue expanders and is a serious alternative to ADM.

\section{Acknowledgements}

The author express his gratitude and would like to thank doctors Gerald Filip, Simona Filip, Ruxandra Ciofu, Radu Despa, Dragos Kinn and the following institutions Ponderas Academic Hospital and Life Memorial Hospital Medlife Bucharest for the great support and care.

\section{Conflict of Interest}

The author declare no conflicts of interests.

\section{Ethics Approval}

All procedures performed were in accordance with the ethical standards of the 1964 Helsinki Declaration and its later amendments.

\section{References}

1. Spear SL, Parikh PM, Reisin E, Menon NG. Acellular dermis assisted breast reconstruction. Aesthetic Plast Surg. 2008:32(3): 418-25.

2. Breuing $\mathrm{KH}$, Warren $\mathrm{SM}$. Immediate bilateral breast reconstruction with implants and inferolateral AlloDerm slings. Ann Plast Surg. 2005;55(3): 232-9.

3. Cordeiro PG, McCarthy CM. A single surgeon's 12-year experience with tissue expander/implant breast reconstruction: part I. A prospective analysis of early complications. Plast Reconstr Surg. 2006;118(4):825-831.

4. Lee MA, Miteff KG. The scarless latissimus dorsi flap provides effective lower pole prosthetic coverage in breast reconstruction. Plast Reconstr Surg Glob Open. 2014:2(5):e147.

5. Lin CH, Wei FC, Levin LS, Chen MC. Donor-site morbidity comparison between endoscopically assisted and traditional harvest of free latissimus dorsi muscle ap. Plast Reconstr Surg. 1999;104(4):1070-7.

6. Elliott LF, Ghazi BH, Otterburn DM. The scarless latissimus dorsi flap for full muscle coverage in device-based immediate breast reconstruction: an autologous alternative to acellular dermal matrix. Plast Reconstr Surg. 2011;128(1):71-79

7. Jagsi R, Jiang J, Momoh AO, Alderman A, Giordano SH, Buchholz TA, et al. Trends and variation in use of breast reconstruction in patients with breast cancer undergoing mastectomy in the United States. J Clin Oncol. 2014:32(9):919-26

8. Jeevan R, Cromwell DA, Browne JP, Caddy CM, Pereira J, Sheppard C, et al. Findings of a national comparative audit of mastectomy and breast reconstruction surgery in England. J Plast Reconstr Aesthet Surg. 2014; 67(10):1333-44.

9. Apfelberg DB, Laub DR, Maser MR, Lash H. Submuscular breast reconstruction: Indications and techniques. Ann Plast Surg. 1981;7(3):213-21.

10. Maxwell GP, Gabriel A. Use of the acellular dermal matrix in revisionary aesthetic breast surgery. Aesthet Surg J. 2009;29(6):485-93.

11. Stump A, Holton LH III, Connor J, Harper JR, Slezak S, Silverman RP. The use of acellular dermal matrix to prevent capsule formation around implants in a primate model. Plast Reconstr Surg. 2009:124(1):82-91.

12. Chun YS, Verma K, Rosen H, Lipsitz S, Morris D, Kenney P, et al. Implantbased breast recon- struction using acellular dermal matrix and the risk of postoperative complications. Plast Reconstr Surg. 2010;125(2):429-436.

13. Lanier ST, Wang ED, Chen JJ, Arora BP, Katz SM, Gelfand MA, et al. The effect of acellular dermal matrix use on complication rates in tissue expander/ implant breast reconstruction. Ann Plast Surg. 2010;64(5):674-8.

14. Antony AK, McCarthy CM, Cordeiro PG, Mehrara BJ, Pusic AL, Teo EH, et al. Acellular human dermis implantation in 153 immediate two-stage tissue expander breast reconstructions: Determining the inci- dence and significant predictors of complications. Plast Reconstr Surg. 2010;125(6): 1606-1614.

15. Hammond DC. Latissimus dorsi flap breast reconstruction. Clin Plast Surg. 2007:34(1):75-82; abstract vi-vii.

16. Sood R, Easow J, Konopka G, Panthaki ZJ. Latissimus dorsi flap reconstruction. Recent innovations in the workhorse flap. Cancer Control. 2018; 25(1):1073274817744638 